\title{
Revisiting the language factor in Zionism: The Hebrew Language Council from 1904 to 1914*
}

\author{
İlker Aytürk \\ Bilkent University, Turkey \\ ayturk@bilkent.edu.tr
}

\begin{abstract}
The role of language and linguistic-philological studies in the nationalist movements of the nineteenth century received much attention. The aim of this article is to focus on the language factor in Zionism and the revival of Hebrew as a spoken language in the Yishuv between 1904 and 1914. Founded in 1904, the Hebrew Language Council was expected to enhance the process of revival and, from the very beginning, an unmistakably nationalist attitude to its subject matter marked the Council's agenda. However, the authority of the Council to make binding decisions on linguistic matters was contested by a number of other Zionist institutions, a development which ruined the prestige and effectiveness of the Council. The controversy resulted less from a turf war or quarrels over scarce resources than a deeper question of which institution represented the "true" Hebraic spirit. The World Zionist Organization's decision to dealign from cultural matters, including the revival of Hebrew, worsened the conditions under which the Council operated. From a comparative perspective, thus, the Hebrew case provides an unusual case of linguistic nationalism, which should be of interest to students of both nationalism and sociolinguistics.
\end{abstract}

The majority of the scholars in the field of nationalism studies today agree on the modernity of nations and believe nations to be "constructs", "artefacts" or "imagined communities", invented by a host of nationalist ideologues since the late eighteenth century. Scholars such as Hans Kohn, Karl Deutsch, Elie Kedourie, Ernest Gellner, Eric Hobsbawm, and Benedict Anderson ${ }^{1}$ all claimed that the

* I am indebted to Smadar Barak, former director of the Dr Aharon Mazie Institute in Jerusalem, for making their collection of documents available to me. This article grew out of a conference paper, which I prepared for "imagiNATION: The Cultural Praxis of Zionism" Conference, Tempe, Arizona State University, 5-7 February 2006. I would like to thank Arieh Saposnik and Shai Ginsburg, the organizers of that meeting, as well as Avigdor Levy, Gideon Shimoni and an anonymous reviewer for their valuable comments and suggestions on earlier versions. All remaining errors are mine.

1 Hans Kohn, The Idea of Nationalism: A Study in Its Origins and Background (New York: The Macmillan Company, 1944); Karl W. Deutsch, Nationalism and Social Communication: An Inquiry into the Foundations of Nationality (New York: The MIT Press and John Wiley \& Sons, 1953); Elie Kedourie, Nationalism, 4th ed. (Oxford and Cambridge, MA: Blackwell, 1993); Elie Kedourie, Nationalism in Asia and Africa (New York and Cleveland: The World Publishing Company, 1970); Ernest Gellner, Nations and Nationalism (Oxford and Cambridge, MA: Blackwell, 1983); Eric J. Hobsbawm, Nations and Nationalism since 1780: Programme, Myth, Reality, 
so-called objective factors, such as common descent, language, shared history and traditions, which were thought to have made a social group a nation, are actually secondary in importance compared to ideology. In the case of the language factor in nationalism, Hans Kohn argued that "[t]he spoken language was accepted as a natural fact", before the age of nationalism and "[i]t was in no way regarded as a political or cultural factor, still less as an object of political and cultural struggle". 2 According to this modernist school, even language, which used to play the most important role in delimiting the borders of a nation, should be subjected to historical scrutiny in order to find out how nationalist philologists and linguists crafted a common idiom for their nations out of an assortment of vernaculars. Likewise, Liah Greenfeld suggested a new model for studying the relationship between nationality and language:

National, as any other, identity frequently utilized the available primordial or "ethnic" characteristics of a population, such as language, which contributed to its sense of uniqueness. Yet it should be realized that such characteristics in themselves do not constitute an identity, but represent elements which can be organized and rendered meaningful in various ways, thus becoming parts of any number of identities... . As much as language, these are universal attributes of human groupings; in distinction, national identity is an historically circumscribed, modern phenomenon, and cannot be explained by its association with such universal attributes. Any one ethnic element serves as the raw material for the national identity only if interpreted as an element of nationality, namely when the principle of nationalism is applied to and bestows on it a new significance. ${ }^{3}$

Instead of attributing a single, predetermined function to language, Greenfeld maintained that each national movement might utilize and exploit its language in a different way to others and that it is the task of the historian to uncover the unique nature of each such relationship.

The processes of language purification, standardization and lexical modernization $^{4}$ in the hands of usually nationalist linguists involve an unavoidable element of artificiality and it is absolutely crucial to analyse and explain the motives of both the makers of national languages as well as those who provide them with political clout to legitimize the endeavour. This article explores how

2nd ed. (Cambridge: Cambridge University Press, 1997); Benedict Anderson, Imagined Communities: Reflections on the Origin and Spread of Nationalism, rev. ed. (London and New York: Verso, 1996). Anthony Smith, who also accepts the modernity of nations, does not, however, consider them pure inventions. He argued that ethnic baggage, whose elements would be forged into a new political reality for the construction of the nation, is invariably necessary. See Anthony D. Smith, The Ethnic Revival (New York: Cambridge University Press, 1981); and The Ethnic Origins of Nations (Oxford and Cambridge, MA: Blackwell, 1986).

2 Kohn, The Idea of Nationalism, 6-7.

3 Liah Greenfeld, "Nationalism and language", The Encyclopedia of Language and Linguistics, 1994 ed., 2709-10.

4 Sociolinguists refer to these processes as corpus-planning and status-planning. 
the Hebrew language, which had ceased to be a spoken language for everyday purposes, came back to life in the Yishuv at the end of the nineteenth and the beginning of the twentieth centuries, and particularly addresses the role of the Hebrew Language Council ( $\mathrm{Va}^{\mathrm{c}} \mathrm{ad}$ ha-lashon ha-ivrit) in that process. The revival of Hebrew as a spoken language is often regarded as one of the greatest achievements of Zionism. Very few people at the time actually believed that the revivalist movement would eventually succeed. For example, one famous scholar of Semitic studies from Germany, Theodor Nöldeke, assumed as late as 1911 that:

The dream of some Zionists, that Hebrew - a would-be Hebrew, that is to say - will again become a living, popular language in Palestine, has still less prospect of realisation than their vision of a restored Jewish empire in the Holy Land. ${ }^{5}$

Such was the success of the revivalist movement, however, that the Mandatory authorities found a small contingent of native Hebrew speakers in Palestine in the early 1920s, whose numbers continued to increase up to the establishment of the State of Israel in 1948. Although the Hebrew Language Council played a central role in the revival, relations among its members on the one hand, and relations between the Council and other Zionist institutions, on the other, were far from friendly. Obstruction of the Council's work reached such proportions before the First World War that there was practically no institution in the Yishuv officially in charge of reviving Hebrew. This made the revival unique in another sense: unlike many other cases of language-planning, Modern Hebrew is not the handiwork of a state apparatus, nor did it benefit from the co-ordination of national resources at its disposal. Because the Hebrew Language Council failed to generate a consensus on what post-revival Hebrew should be like and to impose its decisions on the Hebrew-speaking population of the Yishuv, the revival took place in a chaotic and, one is tempted to say, democratic environment, distinguishing the Hebrew case from others in which official or semi-official institutions often monopolized the process.

\section{The context of revival}

Hebrew was already being spoken in Ottoman Palestine as a lingua franca among Jews of the Old Yishuv, who arrived from different parts of the Jewish world and found Classical Hebrew the most suitable medium for daily interaction. ${ }^{6}$ One did not have to wait until the end of the nineteenth century

5 Professor Marc Zvi Brettler brought this excerpt to my attention. Theodor Nöldeke, "Semitic languages", The Encyclopedia Britannica, 1911, 11th ed., 622. Events proved Nöldeke wrong on both accounts.

6 Tudor V. Parfitt, "The use of Hebrew in Palestine, 1800-1882", Journal of Semitic Studies 17, 1972, 237-52; Uzzi Ornan, "Hebrew in Palestine before and after 1882", Journal of Semitic Studies 29, 1984, 225-54; Tudor Parfitt, "The contribution of the Old Yishuv to the revival of Hebrew", Journal of Semitic Studies 29, 1984, 255-65. 
to witness the foundation of the earliest societies and clubs focusing on the Hebrew language. One such club, the Hevrat dorshei leshon ever (The Society of Friends of the Hebrew Language, or in German, Die Gesellschaft der hebräische Literaturfreunde), was founded in Königsberg in 1782. However, this and other early institutions reflecting concern for the future of the Hebrew language cannot be described as an indication of nationalism since they aimed to revive Hebrew as a literary language only. ${ }^{7}$ Linguistic nationalism, on the other hand, can be defined as an action-oriented idea, which aims to revive, enrich and standardize the language of an ethnic community in all walks of life, and to make this language co-extensive with present or future political boundaries. In other words, linguistic nationalism reconstructs an all-purpose language for a polity, usually a nation-state. It is that correlation between a political ideology and linguistic/philological work that distinguishes linguistic nationalism from earlier attempts to revive folk languages or from the romantic devotion to local dialects and vernacular languages. ${ }^{8}$ The foundation of two societies in Jerusalem towards the end of the nineteenth century, one with the sole aim of reviving the Hebrew language, marks the beginning of this type of a consciousness among Jewish nationalists in the Yishuv - a term that describes the Jewish society in Ottoman and Mandatory Palestine. ${ }^{9}$

7 Isaac E. Barzilay, "National and anti-national trends in the Berlin Haskalah", Jewish Social Studies 21, 1959, 165-92; Yosef Yitzhaki, "De'oteihem shel sofrei ha-haskalah al ha-lashon ha-ivrit u-darkeihem be-harhavatah ve-hidushah", Leshonenu 35, 1971, 287-305; Moshe Pelli, The Age of Haskalah: Studies in Hebrew Literature of the Enlightenment in Germany (Leiden: E. J. Brill, 1979), 73-90; Yaacov Shavit, "A duty too heavy to bear: Hebrew in the Berlin Haskalah, 1783-1819, between classic, modern, and romantic", in Lewis Glinert (ed.), Hebrew in Ashkenaz: A Language in Exile (New York and Oxford: Oxford University Press, 1993), 111-28; Israel Bartal, "From traditional bilingualism to national monolingualism", in Hebrew in Ashkenaz, 141-50.

8 For a thorough discussion of the language factor in nationalism, see Einar Haugen, "Dialect, language, nation", American Anthropologist 68, 1966, 922-35; Carl Darling Buck, "Language and the sentiment of nationality", The American Political Science Review 10, 1910, 44-69; Joshua A. Fishman, Language and Nationalism: Two Integrative Essays (Rowley, MA: Newbury House Publishers, 1973); Maurice Olender, The Languages of Paradise: Race, Religion, and Philology in the Nineteenth Century, trans. Arthur Goldhammer (Cambridge and London: Harvard University Press, 1992); Mary Anne Perkins, Nation and Word, 1770-1850: Religious and Metaphysical Language in European National Consciousness (Aldershot: Ashgate, 1999); Stephen Barbour and Cathie Carmichael (eds), Language and Nationalism in Europe (Oxford: Blackwell, 2000).

9 Those societies were founded in Jerusalem, but the initial impetus for the revival of languages originated from the hotbed of nineteenth-century nationalism that was East and Central Europe. For similar cases, see Robert Auty, "The linguistic revival among the Slavs of the Austrian Empire, 1780-1850: the role of individuals in the codification and acceptance of new literary languages", The Modern Language Review 53, 1958, 392-404; Robert Auty, "Language and nationality in East-Central Europe, 17501950", Oxford Slavonic Papers, New Series 12, 1979, 52-83; Tomasz D. I. Kamusella, "Language as an instrument of nationalism in Central Europe", Nations and Nationalism 7, 2001, 235-51. 
According to the working programmes of two societies, Tehiyat Yisra'el (The Revival of Israel) ${ }^{10}$ and Safah Berurah (Clear Language), ${ }^{11}$ founded in 1882 and 1889 respectively, the revival of the Hebrew language complemented the regeneration of the Jews, or rather the Hebrews, as a political nation. How and why those two societies ceased to function is not clear, but their activities came to an end by mid-1891. As a result, for more than a decade there was no institutional framework in Ottoman Palestine to promote and organize the revival of Hebrew as a spoken language. In the meantime, Hebrew education continued to expand in Jewish schools located in the agricultural settlements called the moshavot (singular moshavah). ${ }^{12}$ Yet this led to a somewhat chaotic situation in which individual schools, or sometimes individual teachers, coined and taught a different Hebrew terminology according to their own taste. In some cases the newly coined words or terms were ad hoc inventions that did not necessarily make sense from a morphological point of view. Even those that were correct and sound were sometimes restricted to a small locality, and would be unintelligible in another town, village or even the next classroom. The chaos in vocabulary, and sometimes in pronunciation - Ashkenazi versus Mizrahi - contradicted the very rationale of the Hebrew revival: the holy tongue was being secularized and revived for daily use, in order to unite the multi-lingual Jewish communities who would otherwise have had difficulty in communicating with fellow Jews. Developments in the Yishuv, however, might well have produced a new generation, referred to as the dor ha-pelagah - literally a divided generation, ${ }^{13}$ conversant not in Hebrew but in many Hebrews. ${ }^{14}$

10 Document No. 11: "Sefer berit shel tehiyat yisra'el", in Ketavim le-toldot hibat tziyon ve-yishuv eretz-yisra'el, vol. 1, ed. A. Druyanov (Odessa: Omanut, 1919), 24-5; or see "Tehiyat yisra'el", in Kol kitvei Eliezer Ben-Yehuda, vol. 1 (Jerusalem-Talpiyot: Ben Yehuda hotza'ah le-or, 1943), 189-90.

11 Yosef Lang, "Safah berurah - le-verur yisudah ve-hitpathutah", Katedrah 68, 1993, 6779; Document No. 960, "Mikhtav ha-takanot hevrat safah berurah", in Ketavim le-toldot hibat tziyon ve-yishuv eretz-yisra'el, vol. 2, ed. A. Druyanov (Tel Aviv: Defus ko'operativi ha-po"el ha-tza'ir, 1925), 784-7; "Va'ad ha-sifrut be-fe'ulato", in Leket te 'udot le-toldot va'ad ha-lashon ve-ha-akademiyah la-lashon ha-ivrit (tara"n - tasha"l) u-le-hidush ha-dibur ha-ivri (Jerusalem: The Academy of the Hebrew Language, 1970), 24.

12 For a case study, see Yosef Lang, "Tehiyat ha-lashon ha-ivrit be-Rishon Le-Tziyon, 1882-1914", Katedrah 103, 2002, 85-130.

13 The dor ha-pelagah referred to the generation of the Tower of Babel, whose speech God confounded; see, Gen. 11: 1-9.

14 Two teachers in the Galilee, for instance, taught Hebrew with a different pronunciation, close to Arabic. A generation or two in that region continued to speak with that particular accent and Israeli linguists have studied it as a dialect. See Aaron Bar-Adon, The Rise and Decline of a Dialect: A Study in the Revival of Modern Hebrew (The Hague: Mouton, 1975). On the fear of dor ha-pelagah, see Ahad Haam's words in "Pratei-kol mi-yeshivat ha-merkaz [agudat ha-morim] be-16 heshvan tar'a"v", Dr Aharon Mazie Institute, The Collection of the Papers of the Hebrew Language Council, Document No: 28 , Jerusalem. The collection housed at the Dr. Aharon Mazie Institute (hereafter Mazie Archive) is the principal source for writing the history of the Hebrew Language Council. All Hebrew dates are converted to the Gregorian calendar. 


\section{The Hebrew Language Council as a national(ist) institution}

The danger posed by that problem was finally recognized in 1903 at the founding convention of the Eretz Israel Teachers' Union (Agudat ha-morim be-eretz yisra'el, later Histadrut ha-morim $)^{15}$ at Zikhron Yaakov. Taking into consideration the random and unmethodical expansion of Hebrew in the hands of a few individuals and the absence of any public activity to bolster the status of Hebrew in Palestine, the Central Committee of the Teachers' Union assumed the task of establishing a "society of linguists". 16 The Union could not act upon its decision immediately for lack of funds, but in its second convention a year later in Gedera, linguistic issues were discussed in detail; moreover, the speakers and teachers alike stressed the need for an up-to-date Hebrew dictionary. ${ }^{17}$ The earliest documents that carry the letterhead of the Hebrew Language Council (hereafter HLC) are from the year 1904. Thus, we can assume that the HLC must have commenced its activities as soon as the Union began funding it. Although the HLC existed as a recognized institution after 1904, its members were rarely able to hold regular meetings and it remained inactive for long periods. From 1904 to 1909, meetings were held once a month at best and, from the summer of 1909 to the end of 1910, there were no meetings at all. From 1911 the HLC resumed its activities on a more or less regular basis, thanks to the injection of much-needed funds from a variety of philanthropic Jewish associations and Zionist organizations.

The principles that guided the work of the HLC in those early years, and surely there must have been some, did not come down to us in print. At its first meeting in 1911, after a long period of inactivity, members of the HLC discussed whether they had the moral authority to invent new words and grammatical forms for the Hebrew language and in the name of the Jewish people. They unanimously decided that they indeed had such clout, given the pressure in the Yishuv and the fact that they had no time to wait for the arrival of expert

15 On the history and influence of the Teachers' Union, see Rahel Elboim-Dror, Ha-hinukh ha-ivri be-eretz yisra'el, vol. 1 (Jerusalem: Yad Yitzhak Ben Tzvi, 1986), 206-39; Rahel Elboim-Dror, Ha-hinukh ha-ivri be-eretz yisra'el, vol. 2 (Jerusalem: Yad Yitzhak Ben Tzvi, 1990), 180-96. Hebrew teachers in Ottoman Palestine started to hold meetings as early as 1891 and these continued until 1896. For the minutes of the debates, see Document No. 1351, "Sefer zikhron devarim la-asefat ha-morim be-eretz yisra'el", in A. Druyanov (ed.), Ketavim le-toldot hibat tziyon ve-yishuv eretz-yisra'el, vol. 3 (Tel Aviv: Defus ko'operativi 'ahdut, 1932), 963-1012.

16 "Le-toldot va'ad ha-lashon", Zikhronot va 'ad ha-lashon, 1, 1912, 4. This short introduction to the first issue of the HLC's proceedings is an invaluable source in tracing the early history of the revival in the Yishuv. It is not entirely reliable, though, since the authors of this text, probably Eliezer Ben-Yehuda and David Yellin, tried to portray the revival as a continuous, unbroken process. That is why they identify the Safah Berurah with the Language Council and push the date of the foundation of the HLC back to 1889, although the two were different institutions both nominally and in terms of their structure.

17 Zikhronot ha-devarim la-asefah ha-kelalit ha-shenit la-agudat ha-morim be-eretz yisra'el (be-yemei 22-25 elul tarsa"d, be-moshavat gedera be-yehudah) (Jerusalem: Defus Rav Avraham Moshe Luncz, 1905), 6-7 and 36-51; Takanot agudat ha-morim be-eretz yisra'el hutz'u me'et merkaz ha-morim ve-tuknu ve-ushru ba-asefat ha-morim ha-kelalit ha-shenit be-elul tarsa"d (Jerusalem: Defus Avraham Moshe Luncz, 1905). 
linguists for this task. Central to their argument was the claim that their geographical location specifically qualified them to undertake the creation of new Hebrew words and forms, since it was in Eretz Israel that Hebrew came to life again and was being spoken on a daily basis, those being conditions that did not apply elsewhere in the Jewish world. ${ }^{18}$ The issue of the HLC's authority, the degree of its control over the Hebrew language, and whether that authority should be shared with the Diaspora Jews and Jewish organizations, constituted problems that continued to trouble its relationship with them. The intricate web of financial links between the HLC and its donors highlights a fascinating power struggle over the determination of the respective extent of influence by each institution or individual over the making of the Hebrew language and, hence, the creation of the new Hebrew identity. The struggle usually took place between the Diaspora institutions and the institutions of the Yishuv, but occasionally relations within the Yishuv were also characterized by the desire to dominate or control. In order to understand the sources of tension and mechanisms of control, it is necessary to analyse the program of the HLC, which can be found in the first issue of its proceedings.

The celebrated author of a comprehensive Hebrew dictionary, Eliezer Ben-Yehuda, ${ }^{19}$ still revered today as the father of Modern Hebrew, recommended the guiding principles which were subsequently voted on and accepted by all members. ${ }^{20}$ Accordingly, the mission of the HLC was threepronged. First, it sought to transform Hebrew into spoken language in all spheres of life: at home, in schools, in public life, trade, industry, arts, philosophy and sciences. Second, the HLC was to safeguard the oriental quality of the Hebrew language and to determine the exact pronunciation of its letters. Finally, the council also took upon itself the duty to provide Hebrew with the required flexibility to make possible the expression of every aspect of human thought. ${ }^{21}$ The working programme of the HLC was more detailed and explained the methodology of lexical modernization. Council members aimed to give priority to finding and publishing lesser-known Hebrew words from

18 "Le-toldot va'ad ha-lashon", 10-11.

19 Reuven Brainin (ed.), Sefer zikaron le-Eliezer Ben-Yehuda (New York: Ha-histadrut ha-ivrit be-amerikah, 1918); Yosef Klausner (ed.), Eliezer Ben-Yehuda: Kovetz le-zikhro (Jerusalem: Ha-solel, 1924); Hemda Ben-Yehuda, Ben-Yehuda: Hayav u-mif'alo (Jerusalem: Ben-Yehuda - Hotza'ah la-or, 1940); Robert St. John, Tongue of the Prophets: The Life Story of Eliezer Ben Yehuda (Garden City, NY: Country Life Press, 1952); Jack Fellman, The Revival of a Classical Tongue: Eliezer Ben Yehuda and the Modern Hebrew Language (The Hague and Paris: Mouton, 1973); Eisig Silberschlag (ed.), Eliezer Ben-Yehuda: A Symposium in Oxford (Oxford: Oxford Centre for Postgraduate Hebrew Studies, 1981); Yosef Lang, Itonut E. Ben-Yehuda ve-amadoteiha be-inyanei ha-yishuv ha-yehudi ve-ha-tenu'ah ha-le'umit ba-shanim 5745-5775 [1884-1914], PhD Dissertation, Bar-Ilan University, Ramat Gan, 1992; Yosef Lang, Daber ivrit: Hayei Eliezer Ben-Yehuda, 2 vols. (Jerusalem: Yad Yitzhak Ben Tzvi, 2008).

20 "Le-toldot va'ad ha-lashon", 11. Members of the $\mathrm{Va}$ 'ad at that initial stage were Eliezer Ben Yehuda, Hayim Zuta, David Yellin, Dr Aharon Mazie, Yosef Meyuhas and E. Sapir. Israel Halevi Teller and Avraham Moshe Luncz joined in in 1907. By 1914 there were about twelve members.

21 Ibid., 11-12. 
Jewish texts and to adapt them to modern use. If an ancient Hebrew word could not be found for a modern concept, the HLC would step in to fill the gap by creating new words. In the act of invention, it would consider mainly Hebrew roots; roots from the Aramaic cognate could be considered if no Hebrew root was applicable, and even then the Aramaic root had to be hebraicized in pronunciation, gender and spelling.

Next were roots from other Semitic languages. The poverty of the Hebrew language in those days, particularly in terms of expressing items in modern households or daily life, encouraged Ben-Yehuda to consider more seriously borrowing words and idioms from other Semitic languages. ${ }^{22} \mathrm{He}$ arrived at the conclusion early on that Hebrew can and should borrow from its cognate languages within the same linguistic family. In a letter he co-authored with Y. M. Pines to Rabbi Shmuel Yosef Fein in 1883, they explained one of the aims of Tehiyat yisra'el in the following way:

... to revive our language with the help of the Arabic language, which has plenty of words and beauty and which is not short of anything, to take from it all that is lacking in our language and to give them a Hebraic form to the extent that one cannot tell where they came from $\ldots . .^{23}$

Ben-Yehuda described the impact of Arabic on his philological studies years later in 1918 in the Prolegomenon of his grand dictionary:

Arabic, in particular, was a kind of source of salvation for me in the linguistic research of our language. First, because it lives at this moment, we are standing on solid ground when explaining the meaning of its words. Second, as I have already proved in one of my papers at one of the Language Council meetings ... very ancient grammatical forms of all the Semitic languages have been preserved for us in Arabic; and its very expansive and rich vocabulary is the joint treasury of all the Semitic languages. The deeper I went into Arabic language research, the wider the gates of understanding of the Hebrew language opened before me; the Arabic vocabulary enabled me to discover the authentic explanation of many biblical words... . ${ }^{24}$

It has to be mentioned though that Ben-Yehuda continued to indulge himself in Arabic studies in spite of the resistance of his colleagues at the HLC. He had indeed read a paper on this issue, as he noted in the above quotation, at one of the regular council meetings and proposed to incorporate many

22 See Avihai Shivtiel, "Languages in contact: the contribution of the Arabic language to the revival of Hebrew", Journal of Semitic Languages 30, 1985, 95-113; and Joshua Blau, The Renaissance of Modern Hebrew and Modern Standard Arabic: Parallels and Differences in the Revival of Two Semitic Languages (Berkeley: University of California Press, 1981).

23 Document No. 46 in Ketavim, ed. Druyanov, vol. 1, 94-6.

24 The translation is by Scott Bradley Saulson. See his Eliezer Ben-Yehudah's Hamavo Hagadol: Introduction, Translation, Annotation, D. Litt. et Phil., University of South Africa, 1985, 70-1. Italics are in the original. 
of the Arabic root stems into the Hebrew language. ${ }^{25}$ Some other members of the Council, E. M. Lifshitz ${ }^{26}$ and Israel Eitan, ${ }^{27}$ opposed this idea on several grounds, the most important being that, as Ben-Yehuda himself recognized, "the majority of the root stems in the Arabic vocabulary had been created in very different [meshuneh] and distant desert life especially when compared to the modern life of city culture". ${ }^{28}$ While Ben-Yehuda prized the vitality of Arabic and the convenience of its roots from a purely linguistic point of view, his colleagues put forward Aramaic as an alternative, mainly for extralinguistic reasons. On the other hand, all members agreed that they would not have recourse to non-Semitic roots, with one exception being the Greek and Roman terms that had passed into Hebrew in antiquity. ${ }^{29}$ In addition to inventing new words, the HLC was also going to give the Hebrew spelling and punctuation a definitive form. It aimed to correct typical pronunciation errors and therefore stressed the differences between the pronunciation of the letters $\pi$ and $כ, x$ and $y$ so as to protect the oriental sound of the language. ${ }^{30}$

\section{National institutions, too, have rivals}

It is striking to see that in its first decade the HLC conjured up an image of itself as the ultimate decision maker in all these spheres. The HLC was no longer the Safah Berurah, a small, disconnected club on the periphery of the Jewish world in Jerusalem. On the contrary, it now expected to be treated as a national institution, charged with a task of national importance. The difference between the image and the reality, however, was too great to go unnoticed. Considering its new role, it was only natural that all Zionist organizations that contributed to the budget and activities of the HLC wanted to influence it in their own particular way.

The most important organization with which the HLC had to collaborate was the Teachers' Union. Its members, usually nationalist teachers, who wanted to teach only in Hebrew did the groundwork in every part of Ottoman Palestine and constituted the grassroots movement of linguistic nationalism. ${ }^{31}$ They were especially influential in the new agricultural

25 "And here dear colleagues, I am proud to announce before you: I have found, I have found! I have found tens, hundreds of Hebrew roots! And I will not conceal from you the place where I found those treasures. Indeed I found them - in Arabic dictionaries." Quoted in Eliezer Ben-Yehuda, "Le-male ha-hoser be-leshonenu", in Zikhronot va 'ad ha-lashon ha-ivrit 4, 1913-14, 8.

26 Ibid., 16-29.

27 Ibid., 29-36.

28 Ibid., 10.

29 "Le-toldot va'ad ha-lashon", 12-14.

30 Ibid.

31 Moshe Rinot, "Ha-morim ve histadrutam", in Toldot ha-yishuv ha-yehudi be-eretz yisra'el me-'az ha-aliyah ha-rishonah: Ha-tekufah ha-otmanit, vol. 1, ed. Israel Kolatt (Jerusalem: Mosad Bialik, 1989), 681-92; Benjamin Harshav, "Masah al tehiyat ha-lashon", Alpayim 2, 1990, 8-54; Benjamin Harshav, Language in Time of Revolution (Berkeley: University of California Press, 1993); Shlomo Morag, "Ha-ivrit ha-hadashah be-hitgabshutah: Lashon be-aspeklariyah shel hevrah", Katedrah 56, 
settlements around Jaffa, the Jezreel Valley, and in the Galilee region. As in other cases of national revival in Eastern and Central Europe, teachers stood at the forefront of the nationalist struggle and generally saw themselves as pioneers of revival. ${ }^{32}$

In the case of Hebrew, the teachers were not only consumers and revivers, but also creators of national language and culture. Inevitably, the teachers' selfimage caused friction between them and the HLC. The problem stemmed in part from the objection raised by both the teachers and the HLC to sharing their creative powers with other individuals or institutions. Another aspect of the problem was the contrast in early Zionist thought between Jerusalem, the so-called bastion of Jewish obscurantism in its being the centre of the Old Yishuv, and the agricultural settlements, where new Hebrew culture flourished. The HLC held its meetings in Jerusalem and most of its members were residents of the town; this certainly did not boost the image of the HLC among the teachers, who considered Jerusalem, and hence the HLC, isolated from "the" national culture of the countryside.

We should also consider the difficult relationship between some members of the HLC and the Second Aliyah (the Jewish immigrants who arrived in Palestine between 1904 and 1914), literally the second wave of immigration to Eretz Israel, in Zionist historiography. The core of this group, who stayed on in Ottoman Palestine and numbered fewer than 5,000, were the bearers of a new ideology, i.e. the labour Zionism. This ideology heralded the regeneration of the Jews on the land of their fathers, provided that they gave up the Diaspora mentality, lifestyle and professions. Their policy of "the conquest of labour" enjoined upon all labour Zionists to take part in physical activity, mostly manual or agricultural labour, in order to "build the land and to be built by it", according to their motto. From 1905, teachers from this group of new immigrants began to join the Teachers' Union and, by 1910, they constituted the majority of the members, a change that was reflected in the relocation of the Union's headquarters from Jerusalem to Jaffa. The new immigrant teachers claimed that they, too, were creators of the new Hebrew culture, particularly through the medium of the revived Hebrew language. ${ }^{33}$ In that sense, teachers believed that Hebrew fell into

1990, 70-92; Shimon Shur, "Modern Hebrew in the light of language planning terminology, history and periodization", Hebrew Studies 37, 1996, 39-54; Shlomo Karmi, Am ehad ve-safah ahat: Tehiyat ha-lashon be-re'iyah bein-tehumit (n.p.: Misrad ha-bitahon, 1997); Shlomo Haramati, Sheloshah she-kadmu le-Ben-Yehuda (Jerusalem: Yad Yitzhak Ben Zvi, 1978); Shlomo Haramati, "Yisrael Halevi Teller: Medakdek-reformator mi-anshei ha-aliyah ha-rishonah", Katedrah 31, 1984, 91-124.

32 See Miroslav Hroch, Social Preconditions of National Revival in Europe: A Comparative Analysis of the Social Composition of Patriotic Groups among the Smaller European Nations, trans. Ben Fowkes (New York: Columbia University Press, 2000); and the collected essays in Mikuláš Teich and Roy Porter (eds), The National Question in Europe in Historical Context (Cambridge: Cambridge University Press, 1993) and Roland Sussex and J. C. Eade (eds), Culture and Nationalism in Nineteenth-Century Eastern Europe (Columbus, Ohio: Slavica Publishers, 1985).

33 On the role of the Second Aliyah in the revival of Hebrew in Palestine, see Aaron Bar-Adon, "Al terumatah shel ha-aliyah ha-sheniyah le-tehiyat ha-lashon ha-ivrit", 
their realm of concern and responsibility at least partially, if not entirely, ignoring the HLC's commission and self-image.

The members of the HLC were far too old-fashioned for the new immigrants. The latter regarded the HLC as a reactionary institution made up of selfproclaimed intellectuals in Jerusalem, who aspired to revive Hebrew as a spoken language, while they were cut off from the centres of the Hebraic revival in Tel Aviv or the moshavot. Eliezer Ben-Yehuda's advocacy of the Uganda plan endeared him neither to the Zionists of Zion ${ }^{34}$ nor to the Second Aliyah. Aharon David Gordon, the prophet of the Jewish return to agriculture, criticized Ben-Yehuda in public, ${ }^{35}$ and Yosef Hayim Brenner wrote a scornful article about him and the HLC in the organ of the socialist Jewish workers, Ha-po ' $\mathrm{el}$ ha-tza ir. ${ }^{36}$

Roused by feedback from its members, the Teachers' Union tried to establish some form of control over the HLC early on. To that end, it founded subcommittees and collaborated with organizations that aimed to spread Hebrew education in the Yishuv. One such organization was the Ivriyah of Jaffa, founded in 1906. The Union informed the HLC in 1908 that the Ivriyah had formed a committee on language, and from then on, the HLC was asked to send the minutes of its meetings to that committee. Furthermore, the Ivriyah committee was going to "determine the areas of study for the HLC so that its work will not be random". 37

Two years later another offshoot of the Teachers' Union, an organization by the name of Kohelet, ${ }^{38}$ approached the HLC with the promise of financial help.

Proceedings of the Ninth World Congress of Jewish Studies (4-12 August 1985, Jerusalem), Division D, vol. 1 (Jerusalem: World Union of Jewish Studies, 1986), 63-70.

34 When, in 1903, the British government contacted the chairman of the World Zionist Organization, Theodor Herzl, and offered Uganda as a destination for immigration and a future homeland, a rift developed within the Zionist movement, dividing it into two camps: the Territorialists and Zionists of Zion. While the former agreed to accept the British plan, the latter opposed it bitterly, eliminating the possibility of settling for anything less than Ottoman Palestine. Walter Laqueur, A History of Zionism (New York: MJF Books, n.d.), 120-30; Ben Halpern and Jehuda Reinharz, Zionism and the Creation of a New Society (New York and Oxford: Oxford University Press, 1998), 141-2. Eliezer Ben-Yehuda emerged as one of the most prominent Territorialists, shocking many of his friends and supporters in the Yishuv. A synopsis of his views on the Uganda Affair, as the problem came to be known, can be found in Eliezer Ben-Yehuda, Ha-medinah ha-yehudit: Ma'amarim shonim al devar hatza'at mizrah-afrikah (Warsaw: I. Edelstein \& Co., 1904).

35 Harshav, Language in Time of Revolution, 106.

36 Y. H. Brenner, "Va'ad ha-lashon mefabrek milim", in Leket te 'udot, 40-1. Also see Ben-Yehuda's reply, "Keitzad bohrim le-va'ad ha-lashon", in Leket te'udot, 43-5. Both articles originally appeared in 1914.

37 The language committee of the Ivriyah consisted of Dr Bograshov, Dr Mossinsohn, Dr Sheinkin, a certain Mr H. Harari, and Mordekhai Ben Hillel Hakohen. Central Committee of the Teachers' Union, Jaffa, to the HLC, Jerusalem, 17 February 1908, Mazie Archive, Document No. 8.

38 Kohelet's full name was Hevrah le-hotza'at sifrei limud u-kvi'ah le-tzorhei batei ha-sefer be-eretz yisra'el. It was founded by the Teachers' Union in order to collect funds specifically for the purpose of preparing and publishing textbooks for the Hebrew schools in the Yishuv. When the Union decided to utilize it as a proxy to the HLC, the Kohelet formed 
One Kohelet circular, sent to the literary elite of the Yishuv as well as to members of the HLC, noted with regret the confusion caused by the large number of amateur language enthusiasts and revivers. The establishment of the HLC in Jerusalem did not solve the problem, according to the Kohelet, because many of the perplexed did not seek help from the HLC (the circular does not mention why) and it failed to establish permanent links to the Hebrew linguists and the literary elite in the Yishuv and abroad. Therefore, the Kohelet offered its services as a proxy between the HLC and the other groups. In other words, it assumed responsibility for reducing the tension between the HLC and its detractors. ${ }^{39}$ However, a crisis of authority erupted between the HLC and the Kohelet soon, following the latter's insistence on its right to publish its own suggested vocabulary. The Kohelet also dared to recommend that the newly invented words by the HLC should first be submitted to language experts and be published only after their approval. In this way, they argued, the HLC's innovations would prove to be more enduring, as they would thus be based on a broader consensus. ${ }^{40}$ Members of the HLC felt greatly insulted by this attitude, rejected all those suggestions, and clarified their position that they were not in any way subordinate to the Kohelet. ${ }^{41}$ A final settlement could be reached only in 1912 at a large meeting in which the representatives of the Teachers' Union, the Kohelet and the HLC participated. Ahad Haam also took part in that meeting, lending the prestige of his name, in order to give its decisions a tone of finality. ${ }^{42}$ It was actually he who tilted the balance in favour of the HLC and prevailed over some other views that were voiced in the meeting by laying emphasis on the need for an authoritative institution in the field of the revival of Hebrew. ${ }^{43}$

a sub-committee, Ve idah le-harhavat ha-safah, that included A. Sapir, M. Krishavsky, A. Gutman, Dr Matman, A. Z. Rabinowitz and H. Harari, mostly teachers in the Jaffa area. See A. Sapir, Jaffa, to the HLC, Jerusalem, 16 November 1910, Mazie Archive, Document No. 14

39 The Kohelet proposed a discussion forum: teachers and other interested amateurs would send in their suggestions and questions to the Kohelet, where they would be debated and then referred to the HLC. The HLC's decisions on those issues would then be returned to all concerned via the Kohelet (ibid). See also Kohelet's circular letter, n.d., Mazie Archive, Document No. 15.

40 A. Sapir, Jaffa, to the HLC, Jerusalem, 9 December 1910, Mazie Archive, Document No. 20.

41 The HLC's reply is missing, but much of its contents were summarized in the Kohelet's following letter. See A. Sapir, Jaffa, to the HLC, 16 December 1910, Mazie Archive, Document No. 21.

42 Ahad Haam (1856-1927) was the ideologue of the Russian Zionists and father of cultural Zionism, a movement that aimed at establishing a Jewish cultural centre in Ottoman Palestine for the rejuvenation of Jewish identity in the Diaspora. For a detailed account of his huge impact on Zionist politics, which should be compared to Theodor Herzl's in effect, see Steven J. Zipperstein, Elusive Prophet: Ahad Ha'am and the Origins of Zionism (Berkeley and Los Angeles: University of California Press, 1993), and Jacques Kornberg (ed.), At the Crossroads: Essays on Ahad Ha-am (Albany: SUNY Press, 1983).

43 "Pratei-kol mi-yeshivat ha-merkaz [agudat ha-morim] be-16 heshvan tar'a"v," Mazie Archive, Document No. 28. Ahad Haam's intervention was in line with his project of establishing a Jewish spiritual centre in Eretz Israel, which would in turn heal and revive Jewish life in the Diaspora. The decisions and practices of the spiritual centre 
The meeting came to an end with a subtle decision that teachers had a role in reviving, but not creating, the Hebrew language. The HLC seemingly received the blessing of all the participants in its new role as the sole authority regarding the language question and it was now officially endowed with the right to enforce its decisions in all Hebrew schools in the Yishuv.

The understanding reached at the meeting could not, however, dissipate the ill will between the parties. Only a few months later, the HLC was obliged to inform the Teachers' Union that there could still be found teachers who did not want to use the terms that had been coined by the HLC and employed their own terminology in their stead. Therefore, the HLC reminded its counterpart that the teachers' resistance breached the new agreement, reached a short while before, and demanded swift action in this matter. ${ }^{44}$ We can safely assume that the dispute continued further, because two years later a new set of decisions was made at the eighth convention of the Teachers' Union that represented an outright violation of the agreement of 1912. Dr. Y. Luria, writing in the name of the Teachers' Union, tried to impose those decisions on the HLC: accordingly, the Union wished to see an expansion in the membership of the HLC with the participation of linguists from within the Yishuv and abroad. Candidates were to be nominated by the HLC, but the Union reserved its right to approve them. One can easily surmise that the aim of the critics of the HLC in using the terms balshanim (linguists) or beki'im (experts) in the correspondence and other documents was to rub salt in the wound; that is, to imply that the members of the HLC lacked the professional competence to accomplish their mission. Indeed, most of the members were amateur linguists and philologists with little formal training in those fields. Secondly, the Teachers' Union requested that the HLC submit all its vocabulary lists to the future linguist members for their authorization prior to publishing and distributing them. The push for expansion and enhancement of the authority of future linguist members clearly signalled scepticism and reservations about the worth of the work of the HLC. The Teachers' Union took one last provocative step to mark the boundaries of the HLC's mandate: it passed a resolution compelling the HLC to accept the Hebrew terms and other vocabulary previously invented by the teachers and already being used in the Yishuv schools. In other words, the HLC was asked to build on foundations it could not dispute or replace. ${ }^{45}$ The argument, for which no agreement was found, was eventually shelved at the outbreak of the First World War.

In such an environment, the unexpected eruption of the War of Languages (milhemet ha-safot) in the Yishuv in late 1913 once again exposed the lack of effectiveness in the HLC. ${ }^{46}$ A minor conflict over the principal language of

should have theoretically taken precedence over those of the Diaspora. Hence the HLC's authority in this field.

44 The HLC, Jerusalem, to the Teachers' Union, Jaffa, 3 July 1912, Mazie Archive, Document No. 63.

45 Dr. Y. Luria, Jaffa, to the HLC, Jerusalem, 29 December 1913, Mazie Archive, Document No. 114.

46 The literature on the War of Languages is growing. The best introduction is in Elboim-Dror, vol. 1, 309-50. In addition, see Yehuda Iloni, "Tziyonei germaniyah u-milhemet ha-safot", Ha-tziyonut 10, 1985, 53-86; Margalit Shiloh, "Milhemet ha-safot 
instruction in the new technical institute in Haifa quickly spilled over to other schools maintained by the German philanthropic organization Hilfsverein, pitting the German-Jewish administrators of the school system against the Zionist teachers, who wanted to substitute Hebrew for German in all courses. From November 1913 to February 1914, the Yishuv exploded in an outburst of nationalist feelings, expressed by publication of pamphlets, newspaper articles, posters and public demonstrations. More than 40 of the Hilfsverein's 56 teachers resigned and founded alternative Hebrew schools with parental approval and collaboration. ${ }^{47}$ More surprising was the level of nationalistic consciousness and commitment exhibited by the students in those schools, and also their organizational skills. In the flagship Hilfsverein educational institution in Palestine, the Teachers' Seminary in Jerusalem, 48 out of 56 students left for a makeshift Hebrew school and gave up their scholarships; in the Boys' School in Jaffa, 120 out of 180 students moved to the Hebrew school; only one student of 83, the son of the janitor, remained in the Hilfsverein school in Haifa. ${ }^{48}$ Desertions from the Hilfsverein system were accompanied by unprecedented student activism in Palestine. Students submitted petitions to school principals, to the Hilfsverein and to important Zionist public figures; they wrote articles for the local Jewish press and the Diaspora newspapers; organized demonstrations and public meetings to protest about German instruction; and occasionally resorted to intimidation and extra-legal measures. ${ }^{49}$ Conversely, the HLC, which could have been expected to lead the tide of opposition, played little part in what can be regarded as the greatest flare-up of linguistic nationalism in the history of the Yishuv. Almost all nationalistic activities for the cause of the Hebrew language were co-ordinated by the Teachers' Union, which could be interpreted as another act of defiance against the HLC. More striking in this case, however, is the HLC's loss of initiative and its apparent acquiescence in its secondary role.

Apart from the animosity of the new immigrants who came with the wave of the Second Aliyah, some other avowedly Zionist institutions were also unwilling to co-operate with the HLC. One such incident was recorded in correspondence with the Anglo-Palestine Bank, revealing the extent to which the HLC was taken lightly and almost as a nuisance in the Yishuv. The Anglo-Palestine Bank had been established in Jaffa in 1903 as an offshoot of the Jewish Colonial Trust, the unofficial bank of the Zionist Organization, under the chairmanship of Zalman David Levontin. ${ }^{50}$ It had branches in all the cities and Jewish

ke-tenu'ah amamit", Katedrah 74, 1994, 87-119; Mme [Hemda] Ben Yehudah, "Palestine before the War", in Jerusalem: Its Redemption and Future, The Great Drama of Deliverance Described by Eyewitnesses (New York: The Christian Herald, 1918), 3-17.

47 The teachers' petition to the Hilfsverein, demanding that Hebrew be made the exclusive medium of instruction, can be found in The Struggle for the Hebrew Language in Palestine (New York: Actions Committee of the Zionist Organization, 1914), 31-5.

48 Ibid., 49-50.

49 Ibid., 36.

50 Derek J. Penslar, Zionism and Technocracy: The Engineering of Jewish Settlement in Palestine, 1870-1918 (Bloomington and Indianapolis: Indiana University Press, 1991), 43 and 68. 
settlements of Ottoman Palestine, the main ones being in Jaffa and Jerusalem. Apparently, in 1912 a member of the HLC visited the Jerusalem branch and in spite of insisting on conversing with the tellers in Hebrew, his request was rebuffed. The attitude of the tellers was discussed at length in the next council meeting, leading to its writing a letter to the branch manager, Mr Yitzhak Levi, to inform him of the deviation from Zionist ideals in his branch. It was noted with sadness that the tellers spoke Hebrew neither among themselves nor with customers, not even those who spoke Hebrew regularly. ${ }^{51} \mathrm{Mr}$ Levi replied immediately with what can be considered a very sarcastic letter: he expressed his pleasure at the HLC's care and concern for the Hebrew language, but argued that they "... see a mote in another's eye and not the beam in one's own". When members of the HLC themselves were known to speak in "jargonit", i.e. Yiddish, or in French with the bank officials, he asked, what right did they have to preach a code of behaviour to others. Levi ended the letter by confirming his and the bank's adherence to the Zionist goals and the ideal of reviving Hebrew, while making it clear that he would not accept an outside intervention, and certainly not one from the HLC. ${ }^{52}$ To understand the full gravity of this letter, it must be emphasized that Yitzhak Levi was by no means an unimportant bank manager in Jerusalem; he was a veteran Zionist and would emerge in 1914 as the Yishuv's candidate for the Ottoman parliament. ${ }^{53}$

Few institutions in the Yishuv demonstrated their interest in co-operating with the HLC and initiated contact. The Maccabee Gymnastic Club in Jaffa, for instance, benefited from the HLC's work on the terminology for physical education classes. When the list of the PE terms was finally ready, the Club ordered 20 copies of the second issue of the HLC's proceedings, which included those terms. ${ }^{54}$ The Jewish Agricultural Experiment Station in Haifa was another Jewish organization that assisted the HLC, this time in its work to prepare botanical terms. The energetic director of the station, Aaron Aaronsohn (better known as the mastermind of the Nili spy network during the First World War), inspected the list submitted to him by the HLC and compared those terms with a list of his own. ${ }^{55}$

\section{The question of language and the World Zionist Organization}

The HLC struggled to assert its linguistic authority in the eyes of other Zionist institutions in the Yishuv and in the diaspora simultaneously. As early as 1907 it had sent letters to many such institutions letting them know it had adopted the

51 The HLC, Jerusalem, to the manager of the Jerusalem branch of the Anglo-Palestine Bank, Jerusalem, 9 July 1912, Mazie Archive, Document No. 65.

52 Yitzhak Levi, Jerusalem, to the HLC, Jerusalem, 14 July 1912, Mazie Archive, Document No. 66א. For the HLC's quite moderate response, see its letter to Yitzhak Levi, Jerusalem, 22 July 1912, Mazie Archive, Document No. 75.

53 Israel Kolatt, "The organization of the Jewish population of Palestine and the development of its political consciousness before World War I", in Moshe Ma'oz (ed.), Studies on Palestine during the Ottoman Period (Jerusalem: The Magnes Press, 1975), 228-9.

54 Maccabee Gymnastic Club, Jaffa, to the HLC, Jerusalem, 2 January 1913, Mazie Archive, Document No. 93.

55 Aaron Aaronsohn, Haifa, to the HLC, Jerusalem, 5 June 1912, Mazie Archive, Document No. 61. 
Mizrahi pronunciation of Hebrew as the authoritative pronunciation. Eliezer Ben-Yehuda in particular made every effort to draw attention to the HLC and to his dictionary project. For this purpose, he travelled in 1911 to Berlin, by then the centre of Zionist activity, and successfully signed a deal with the Organisation für hebräische Sprache und Kultur (Histadrut la-safah u-la-tarbut ha-ivrit) that provided substantial financial support until 1914. ${ }^{56}$

On the eve of World War I the HLC at last received recognition from the World Zionist Organization, which began sponsoring its activities through the Jüdischer Kulturfonds "Kedem" (in Hebrew, Keren ha-tarbut ha-ivrit "kedem"). ${ }^{57}$ From the First Zionist Congress in 1897 up to 1913, the World Zionist Organization chose not to have a cultural policy in general and displayed a lukewarm attitude towards the revival of Hebrew in particular. Several factors accounted for this surprising apathy. To begin with, some of the most important luminaries of the Zionist movement such as the founder of the World Zionist Organization, Theodor Herzl, and the author of Autoemanzipation, Leon Pinsker, grew up as acculturated Jews, whose ties to Jewish learning and tradition were minimal. Even though they worked out plans to establish a state for the Jews, the language of that state did not concern them much. ${ }^{58}$ The most striking example of the indifference towards Hebrew was none other than Herzl himself. His uneasiness in pronouncing Hebrew, for example, caused him great anxiety on occasions when he had to do so:

In deference to religious considerations, I went to the synagogue on Saturday before the Congress. The head of the congregation called me up to the Torah. I had the brother-in-law of my Paris friend Beer, Mr. Markus of Merau, drill the brokhe [benediction] into me. And then I climbed the steps to the altar, I was more excited than on all the Congress days. The few Hebrew words of the brokhe caused me more

56 Eliezer Ben-Yehuda, Berlin, to Hayim Zuta, Jerusalem, n.d., Mazie Archive, Document No. 34x; Shai Ish Hurwitz, Berlin, to Eliezer Ben-Yehuda, Jerusalem, 5 December 1911, Mazie Archive, Document No. 32. As a result of this arrangement, Hurwitz and Hayim Zlatopolski, a Russian Zionist, agreed to transfer 1,200 francs per year to the HLC. In return the HLC agreed to send monthly activity reports to Zlatopolsky and mention the name of the Organisation für hebräische Sprache und Kultur in its publications. See the letters by Shai Ish Hurwitz, Berlin, to the HLC, Jerusalem, 24 February 1911, Mazie Archive, Document No. 23; and Shai Ish Hurwitz, Berlin, to the HLC, Jerusalem, 19 January 1912, Mazie Archive, Document No. 37. See also Histadrut la-safah u-la-tarbut ha-ivrit, Din ve-heshbon shel ha-ve idah la-safah u-la-tarbut ha-ivrit be-vinah (22-25 Av 1913) (Warsaw: Ha-tzefirah, 1914); Elias Hurwicz, "Shai Ish Hurwitz and the Berlin He-Atid: when Berlin was a centre of Hebrew literature", Leo Baeck Institute Year Book 12, 1967, 85-102.

57 Nahum Sokolow, Berlin, to the HLC, Jerusalem, 15 December 1913, Mazie Archive, Document no. 113.

58 Earlier political tractates of Jewish nationalism do not even contain a reference to the role of the Hebrew language. See Moses Hess, Rome and Jerusalem: A Study in Jewish Nationalism, trans. Meyer Waxman, 2nd ed. (New York, 1943 [originally 1862]); and Leon Pinsker's Autoemanzipation: Mahnruf an seiner Stammegenossen von einem russischen Juden in Road to Freedom: Writings and Addresses by Leo Pinsker, ed. Benzion Netanyahu (New York: Scopus, 1944). 
anxiety than my welcoming and closing address and the whole direction of the proceedings. ${ }^{59}$

As regards his Judenstaat, Herzl was afraid that declaring Hebrew the official language of the land might turn the new state into another Jewish ghetto, similar to the effect Yiddish had, according to him, on the Jews of Eastern and Central Europe for centuries. He believed that "... the main language must gain acceptance without constraint. If we found a neo-Hebrew state it will be only a New Greece. But if we do not close ourselves off in a linguistic ghetto, the whole world will be ours". ${ }^{60}$ Herzl held Hebrew in high esteem because respecting one's past and ancestors was what suited a nineteenth-century middle-class gentleman. Yet from a practical point of view, Hebrew did not have a place in the Judenstaat, or in his half-fantastic Altneuland, except for its role as the medium between God and the Jews. Having in mind the model of Switzerland, which constituted and still constitutes a very special case, Herzl presumed that the future Jewish state could survive without a national language:

Someone may think that our lack of a common language would present difficulties. After all, we cannot converse in Hebrew. Who among us knows enough Hebrew to ask for a railroad ticket in this language? We have no such people. But it is really a very simple matter. Everyone retains his own language. I am a German-speaking Jew from Hungary and can never be anything but a German. At present I am not recognized as a German. But that will come once we are over there. And so let everyone keep his acquired nationality and speak the language which has become the beloved homeland of his thoughts. Switzerland offers visible proof that a federated state of different nationalities can exist.

I believe that German will be our principal language. I draw this conclusion from our most widespread jargon, "Judeo-German". But over there we shall wean ourselves from this ghetto language, too, which used to be the stealthy tongue of prisoners. Our teachers will see to that. ${ }^{61}$

He reiterated the same arguments almost verbatim in the text of Der Judenstaat in 1896, of course dropping the reference to his prophecy that German would be the "principal language":

It might be suggested that our want of a common current language would present difficulties. We cannot converse with one another in Hebrew. Who amongst us has a sufficient acquaintance with Hebrew to ask for a railwayticket in that language? Such a thing cannot be done. Yet the difficulty is very easily circumvented. Every man can preserve the language in which

59 Herzl's journal entry from 6 September 1898 in The Complete Diaries of Theodor Herzl, vol. 2, ed. Raphael Patai, trans. Harry Zohn (New York and London: Herzl Press and Thomas Yoseloff, 1960), 588-9.

60 Journal entry from 23 February 1896, ibid., vol. 1, 305-6.

61 Journal entry from 15 June 1895 , ibid., 170-1. Judaeo-German is obviously the Yiddish language. 
his thoughts are at home. Switzerland affords a conclusive proof of the possibility of a federation of tongues [Sprachenföderalismus]. We shall remain in the new country what we now are here, and we shall never cease to cherish the memory of the native land out of which we have been driven.

We shall give up using those miserable, stunted jargons, those Ghetto languages which we still employ, for ours was the stealthy speech of prisoners. Our national teachers will give due attention to this matter; and the language which proves itself to be of greatest utility for general intercourse will be adopted without compulsion as our national tongue [Hauptsprache]. Our communal tie is peculiar and unique, for we are bound together only by the faith of our fathers. ${ }^{62}$

Reading that last sentence, it becomes difficult to understand whether Herzl considered the Jews a nation or a simply a religious community in search of a refuge from the excesses being committed against them. One thing is certain: language was not a factor in the making of the Jewish nationhood, however Herzl defined it.

Another reason for the Zionist Organization's detachment from Hebrew, emerging as a problem to be reckoned with only after 1900-01, was the opposition of religious Zionists to the adoption of cultural policies that could have challenged the monopoly of Jewish orthodoxy in such matters. ${ }^{63}$ Religious Zionists, who were otherwise known as the Mizrahi movement, took part in the Jewish nationalist project in the hope that they could hasten the coming of the Messiah by establishing a divine polity in the Holy Land. Thus, they were interested in Zionism to the extent that it remained a political ideology which aimed to relocate Diaspora Jews to their ancient land. Any attempt by secular Zionists to inculcate their secular version of Jewish identity in other Jews alarmed them, for this exposed the religious Zionists' already precarious position vis-à-vis the non-Zionist, and usually anti-Zionist, orthodox establishment. On the question of introducing cultural issues to the agenda of the World Zionist Organization, the religious Zionists disagreed particularly with the members of the Hibbat Tziyon, who at the time spoke in the name of the majority of Russian Zionists. Under the spiritual guidance of Ahad Haam, the Hovevei Tziyon (lovers of Zion) committed themselves to the cultural revival of the Jews and it was this theme that dominated their discourse, rather than political independence. The Odessa Committee of the Hibbat Tziyon funded projects in and immigration to the Yishuv from 1889 onwards, ${ }^{64}$ striving to create a Jewish cultural centre in Palestine. The clash between those two groups was

62 Theodor Herzl, A Jewish State: An Attempt at a Modern Solution of the Jewish Question, trans. Sylvie D'Avigdor (London: David Nutt, 1896), 88-9.

63 On various brands of religious Zionism, see Aviezer Ravitzky, Messianism, Zionism, and Jewish Religious Radicalism, trans. Michael Swirsky and Jonathan Chipman (Chicago and London: The University of Chicago Press, 1996); Ehud Luz, Parallels Meet: Religion and Nationalism in the Early Zionist Movement, 1882-1904, trans. Lenn J. Schramm (Philadelphia: The Jewish Publication Society, 1988).

64 Gideon Shimoni, The Zionist Ideology (Hanover and London: Brandeis University Press, 1995), 111-2. 
evident from the beginning. ${ }^{65}$ Having understood the importance of maintaining unity within the Zionist movement, on the other hand, and fearing a Kulturkampf in their own ranks, Herzl and David Wolffsohn, who replaced him, tried to remove the so-called "cultural questions" from the agenda of the Zionist congresses. The resistance of religious Zionists could be softened only at the Eleventh Zionist Congress in 1913, which decided, upon Menahem Ussishkin's recommendation, to throw its full support behind the aforementioned Kedem. The foundation of Kedem in 1913, whose slogans were kibush ha-ruah (conquest of the spirit) and am ehad ve-safah ahat (one nation and one language), marked a sea-change in the official language policy of the Zionist Organization. ${ }^{66}$ The change, however, came too late for the HLC, because the much-needed support of the Zionist Organization was not sufficient to overcome the impact of the First World War: when war broke out, Ottoman Palestine became a war zone and the HLC in Jerusalem was truly isolated from the rest of the Jewish world, unable to maintain regular contact even with the Zionist centre in Berlin. Some of its members fled Palestine and others were deported by the Ottoman authorities. Eliezer Ben-Yehuda, the most prominent member of the HLC and the guiding spirit behind the revival process, was among those who fled. The HLC was able to resume its activities only after the British conquest of Palestine in 1918.

\section{Conclusion}

The HLC was unable to attain the national status it aspired to from its foundation in 1904 to 1914. Its weakness stemmed mainly from the absence of a Jewish state apparatus, which would, otherwise, have been instrumental in supporting its activities and enforcing its decisions. ${ }^{67}$ The World Zionist Organization, which could be considered a Jewish quasi-government or government-in-the-making, had not yet penetrated Ottoman Palestine, and the institutions Zionists implanted there functioned under the close scrutiny of Ottoman bureaucrats determined to stifle any Jewish nationalistic tendencies. Moreover, the HLC could never have counted on unequivocal support from the World Zionist Organization, until it revised its cultural policy in 1913. Hence, the HLC operated without the legal and financial assistance of a state, a factor that distinguishes the process of the revival of Hebrew from many other cases of language revivals and reforms elsewhere. The non-state environment also created and fuelled an intense rivalry between the HLC and other institutions of the Hebraic revival, leading to some wrangling over scarce funds and even turf wars. Although one would have expected to observe a

65 Moshe Rinott, "Religion and education: the cultural question and the Zionist movement, 1897-1913", Studies in Zionism 5, 1984, 1-17.

66 Natan Efrati, "Tehiyat ha-lashon ha-ivrit ve-ha-tenu'ah ha-tziyonit", Leshonenu la-am 48, 1997, 112-9. See also the report prepared by Eliezer Ben-Yehuda and David Yellin for the Eleventh Zionist Congress in 1913, Mazie Archive, Document no. 102ג.

67 For the political organization of the Yishuv, see Kolatt, "The organization of the Jewish population of Palestine", 211-45; Yosef Gorni, "Irgun ha-yishuv", in Toldot ha-yishuv ha-yehudi be-eretz yisra'el me'az ha-aliyah ha-rishonah: Ha-tekufah ha-otmanit, Vol. 2, ed. Israel Kolatt (Jerusalem: Mosad Bialik, 2002), 421-4. 
more respectful attitude towards the Council in the Yishuv, this was not the case: in spite of later myth-making efforts to inflate its influence and significance prior to the First World War, the HLC's ascendance to the national pantheon was a post-1918 development during the British military government and the mandatory era. This brings us to the inevitable conclusion that in Zionism we face a very rare, if not unique, phenomenon: a nationalist movement which did not give priority to the language question in much of its early history. From Zionism's first appearance in the 1880s until 1913, neither Hebrew nor any other Jewish language attained any political significance. In other words, the Zionist leadership was quite indifferent to the choice of a national language for the Jewish people during that early stage or at times found it more expedient not to tackle this problem for maintaining unity among its own ranks. In any case, this peculiar relationship between Zionism and Hebrew, or rather its absence, contradicts the findings of a chain of scholars from Karl Deutsch to Ernest Gellner and Benedict Anderson, who essentially consider nationhood a consequence of ever-increasing communication among the nation's members. For this reason alone, the Hebrew case opens new vistas of theoretical inquiry to students of nationalism.

On the other hand, the absence of a Jewish state cannot be considered a completely negative factor, but should rather be regarded as a mixed blessing. With regard to at least one important aspect, disorder and chaos in the field of language planning had a constructive result. In practice, the revival of Hebrew as a spoken language had not been monopolized by a single institution until the $1920 \mathrm{~s}$, with the extraordinary effect that at the earliest crucial stage the task was shouldered by a large number of concerned individuals and organizations, making the revival a more democratic and popular type of language reform and distinguishing it from other reform processes in the world, which were more or less top-down in character. Thanks to the popular participation in the process and, hence, the consensus on the revivalist policy, the revival of Hebrew did not trigger a Kulturkampf between those who supported language reform and those who were against it, a situation that afflicted some other cases. ${ }^{68}$

68 The situation was completely the reverse, for example, in the Turkish case, where conservatives of all stripes clung to an unreformed Ottoman Turkish, while Kemalist reformers continued to speak and write a purified Turkish. 